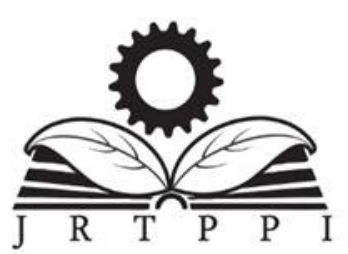

Vol. 10 No. 1 (2019) 1-11

Jurnal Riset

Teknologi Pencegahan Pencemaran Industri

Kementerian

Perindustrian

REPUBLIK INDONESIA

Journal homepage : ejournal.kemenperin.go.id/jrtppi

\title{
Potency to Recycle Hydrapulper Reject Waste of Paper Mill into Composite Particleboard
}

\author{
Andri Taufick Rizaluddin ${ }^{1}$, Yusup Setiawan ${ }^{1}$
}

${ }^{1}$ Balai Besar Pulp dan Kertas (BBPK), Jl. Raya Dayeuhkolot 132 Bandung, Indonesia

\section{A R T IC L E I N F O}

Article history:

Received 04 October 2018

Received in revised form 11 March 2019

Accepted 19 March 2019

Available online 27 May 2019

\section{Keywords :}

Hydrapulper reject

HDPE

Particleboard

Fiber

\begin{abstract}
A B S T R A C T
Solid waste of paper mill hydrapulper rejects (HR) has a relatively high plastic content, with around $45-49 \%$ composition of the total HR. About $99 \%$ of the plastic has the category of High-Density Polyethylene (HDPE). HDPE is a type of Polyethylene (PE) plastic which has high recyclability and may be reformed at high temperature. This study tries to describe the potential of producing particleboards derived from HR using a hot-press method. Molded HR was being hot-pressed at a pressure of $25 \mathrm{kgf} / \mathrm{cm}^{2}$ for $5-15$ minutes of residence time, with a variation of the amount of HR from 150-500 g, and variations in hot-press temperature of $150-180^{\circ} \mathrm{C}$. Products were then analyzed for parameters such as moisture content, density, water absorption, thickness swelling, and internal bond and compared to SNI 03-2105-2006 and JIS A 5908-2003 standard. The results showed that most of the samples were relatively accepted to the SNI, with only a few data could meet JIS. The best results are obtained at $\mathrm{HR}$ weight of $250 \mathrm{~g}$ with 165 and $180^{\circ} \mathrm{C}$ pressing temperature and pressing time more than 10 minutes. The addition of HDPE pellets showed an increment of density and decrement of moisture content of particleboard, while the addition of Maleic Anhydride (MA) showed some decrements of moisture content and water absorption of particleboard.
\end{abstract}

\section{INTRODUCTION}

Corrugating medium and Kraft liner industries in Indonesia usually using waste paper as one of their raw material sources. Mixed waste paper as a raw material may usually consist of many impurities such as plastic, glass, metal, etc. The impurities are usually rejected from the hydrapulper inlet and separated as hydrapulper rejects (HR). The components contained in the HR waste from the paper mill consist of bundles of fibers, foils and plastic pieces that may depend on the quality of the waste paper input.

Plastics content on HR is usually relatively high. A study reported about $45 \%$ plastic content on HR without prior separation (Haynes, Malloch, Cuddy, \& Nicodimos, 2009), while the contents were slightly higher $(49,25 \%)$ after a metal separation treatment from HR (Setiawan, Purwati, Surachman, Bastari, \& Hardiani, 2014). There are several types of plastic wastes that have thermoplastic characteristics and can be formed repeatedly with high temperature such as Polyethylene (PE) (Atuanya, Ibhadode, \& Igboanugo, 2011; Faruk \& Matuana, 2008; Li, Zheng, Pan, \& Hartsough, 2009), Polypropylene (PP) (Ashori \& Nourbakhsh, 2014; Septiari, Karyasa, \& Kartowarsono, 2014), and Polystyrene (PS) (Mawardi, 2009). A study has reported that $99 \%$ of the total plastics content of $\mathrm{HR}$ is a type of High Density Polyethylene (HDPE) plastics (Setiawan \& Surachman, 2015). HDPE is a type of PE plastic that has high recyclability and thermoplastic characteristic. The proportion of plastic in $\mathrm{HR}$ can be seen in Table 1.

\footnotetext{
${ }^{*}$ Correspondence author. Tel. : +6222 5202980

E-mail : andritr@kemenperin.go.id
} 
Table 1. Hydrapulper Rejects Proportion

\begin{tabular}{lcc}
\hline \multicolumn{1}{c}{ Proportion } & $\begin{array}{c}\text { Without metal } \\
\text { separation } \\
\text { (Haynes et al., 2009) }\end{array}$ & $\begin{array}{c}\text { With metal } \\
\text { separation }\end{array}$ \\
\hline $\begin{array}{l}\text { Fiber (paper, } \\
\text { cardboard, etc.) }\end{array}$ & $21.00 \%$ & $50.75 \%$ \\
Plastics & $45.00 \%$ & $49.25 \%$ \\
Metals & $10.00 \%$ & - \\
Others & $24.00 \%$ & - \\
\hline
\end{tabular}

Plastic waste is very difficult and will likely to take a long period of time to decompose in the natural environment. One alternative solution for the management of plastic waste is to recycle them into other derivatives product such as particleboard. Plastics as raw materials for particleboard has characteristics advantage of plastic hydrophobicity which may provide water and moisture resistant characteristics to the particleboard. Also, plastic materials are not preferred by termites, so termites will automatically be avoided without prior preservation treatment, thus no termites repellent addition would be needed to the particleboard.

Generally, the applied HR management is through the disposal to landfills or reducing the amount of HR through incineration without further recycling process (Gavrilescu, 2008). With high fiber and plastic content within it, HR waste has good potential to be used as raw material for particleboard manufacturing. The process of recycling HR into particleboard is one solution to convert solid waste and its treatment cost into economical raw materials. Moreover, the handling of HR may also produce other environmental benefits, including reducing the cost of processing HR waste which has been transported out of the factory to be processed at the third party, cleaning the factory from accumulated HR waste to improve cleanliness, and also improve the factory image in order to support the green industry program.

Particleboard is one type of composite product / wood panel made of wood particles or other lignocellulosic

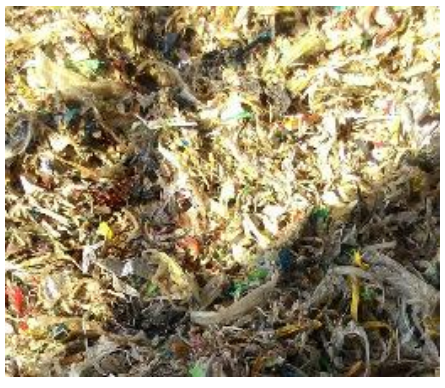

a. Hydrapulper Reject

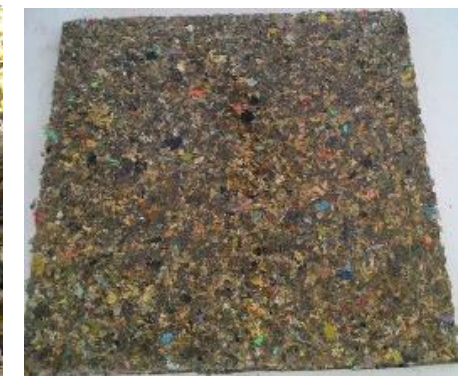

b. particleboard
Figure 1. HR from paper mill and product of particleboard from HR

material, which bonded with adhesive or other bonding material then hot-pressed (Maloney, 1977). Composites are formed from two different types of material, namely: (1) Reinforcement, which is less ductile but rigid and strong, (2) The matrix, generally more ductile but has the strength of lower rigidity.

Previous study has showed a potential of waste paper as particle board (Harshavardhan, Muruganandam, \& Ranjitha, 2016). This research was conducted to study the potential to recycle $\mathrm{HR}$ as a raw material of particleboard.

\section{METHODS}

HR was obtained from corrugating medium and Kraft liner paper mill production process with waste paper (recycled paper) as raw material. HR volume was around 5$10 \%$ of the production capacity with $50-70 \%$ moisture content. Before the shredding process, HR was dried under the sun to reduce the moisture content to less than $10 \%$. Maleic Anhydride (MA) was used for coupling agent additive while HDPE pellet was used for additional adhesive for particleboard sample. MA $\left(\mathrm{C}_{4} \mathrm{H}_{2} \mathrm{O}_{3}\right)$ has a melting point at $52.56^{\circ} \mathrm{C}$ and the boiling point at $202^{\circ} \mathrm{C}$ (at $760 \mathrm{~mm} \mathrm{Hg}$ ) with $98.06 \mathrm{~g} / \mathrm{mol}$ of molecular weight (CAMEO Chemicals, 1999), while HDPE has melting point at 126$135^{\circ} \mathrm{C}$ (Matmatch, 2019).

Equipment used at this study are shredder machine and hot-press machine which has maximum $50 \mathrm{kgf} / \mathrm{cm}^{2}$ 


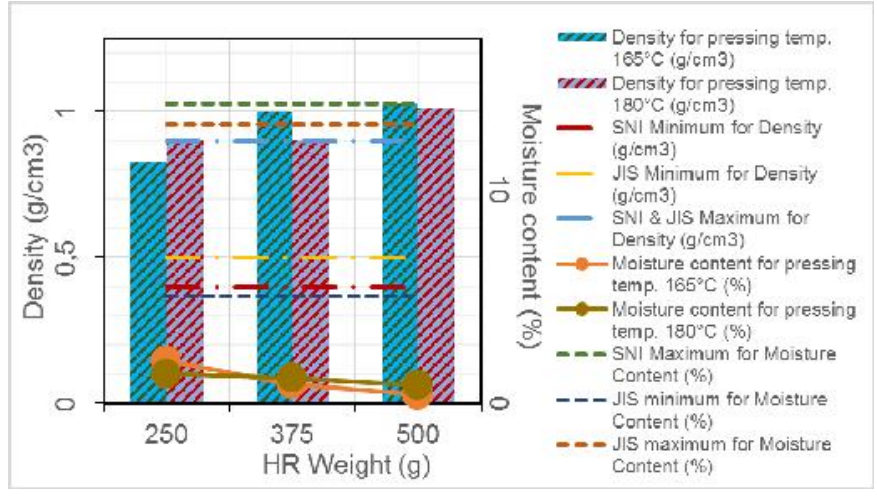

(a)

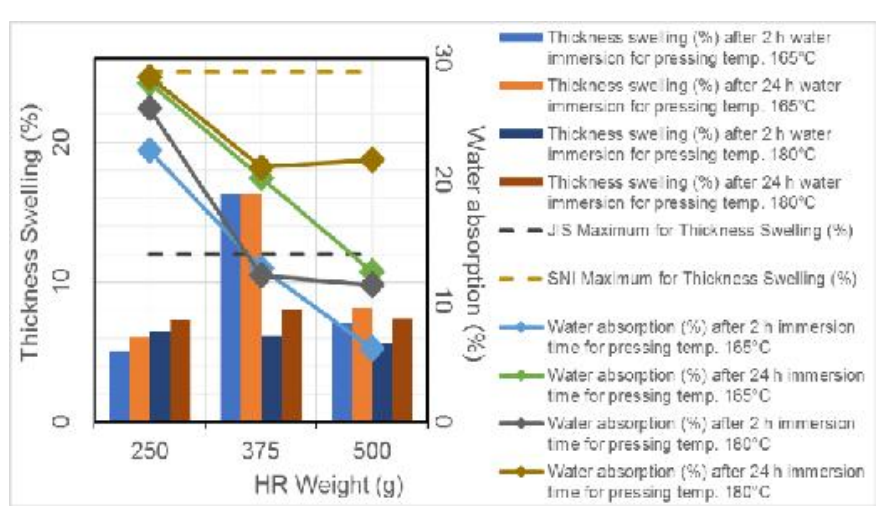

(b)

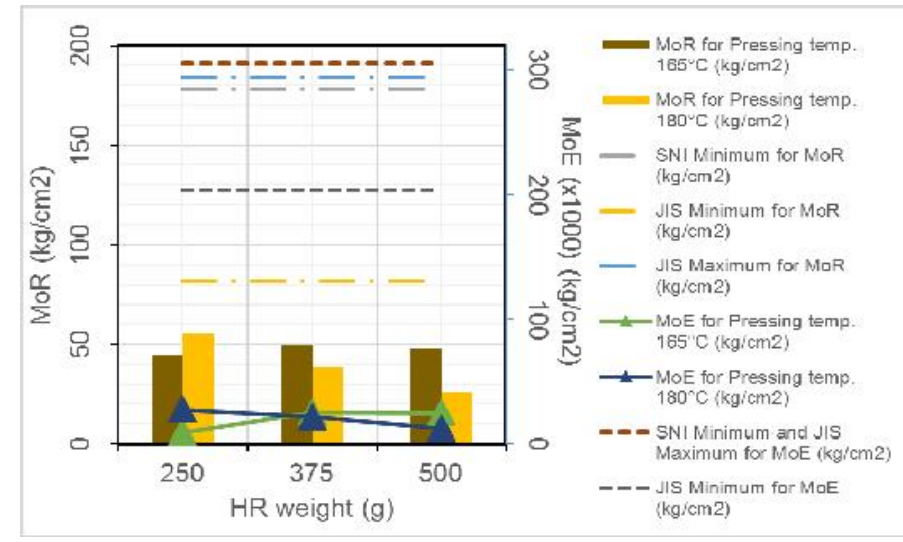

(c)

Figure 2. Effect of different HR weight and pressing temperature on density, moisture content, thickness swelling, water absorption, MoR and MoE

constant pressure, which would fit one mold $\left(20 \times 20 \mathrm{~cm}^{2}\right.$ wide size) and temperature variation up to $200^{\circ} \mathrm{C}$. Shredding of HR was carried out in a shredding/cutting machine. The machine has a blade with approximately 4 $\mathrm{mm}$ holes screen ( $4 \mathrm{~mm}$ mesh) for output of shredded HR with the size about $4 \mathrm{~mm}$. Particleboard molding of HR was carried out using a $20 \times 20 \mathrm{~cm}^{2}$ mold size made of stainless steel with $1 \mathrm{~cm}$ thickness target. Teflon sheet was used at the molding process to avoid sticking product to the mold. The size of the mold $\left(20 \times 20 \mathrm{~cm}^{2}\right)$ was chosen to fit perfectly with the hot-pressed machine previously owned by Center for Pulp and Paper. Molded HR was then being hot-pressed with a hot-press machine, carried out on $25 \mathrm{kgf} / \mathrm{cm}^{2}$ pressure for variation of $5-15$ minutes residence time. Product of particleboard samples was then removed from the hot-press machine and then cooled down at the room temperature. A variation of $\mathrm{HR}$ weight from $150-500 \mathrm{~g}$ and hot-pressing temperature of $150-180^{\circ} \mathrm{C}$ were used in this study. Shredded MR was mixed either with MA (2.5 to 10 wt $\%$ ) or with HDPE plastic pellets (2.44 to $9.09 \mathrm{wt} \%$ ) and then inserted into mold and hot-pressed. The previous study showed that variation on MA size was insignificant (Wardani, Massijaya, \& Machdie, 2013).

Particleboard products were then tested for physical properties including density, moisture content, thickness swelling, and water absorption, and also internal bond, modulus of rupture (MoR) and modulus of elasticity (MoE) as mechanical properties. Thickness swelling and water absorption were tested after 2 and 24 hours of water immersion. Collected data were then compared to Indonesian standards according to SNI 03-2105-2006 which are density $0,4-0,9 \mathrm{~g} / \mathrm{cm}^{3}$, moisture content $<14 \%$, thickness swelling $<12 \%$, internal bond $>1,5 \mathrm{~kg} / \mathrm{cm}^{2}$, MoR $\geq 178$ and $\mathrm{MoE} \geq 30,600$. Japanese standard of JIS A 59082003, was also being compared. Subsequent reference for SNI and JIS refers to SNI 03-2105-2006 and JIS A 59082003 respectively. Although water absorption is not one of 


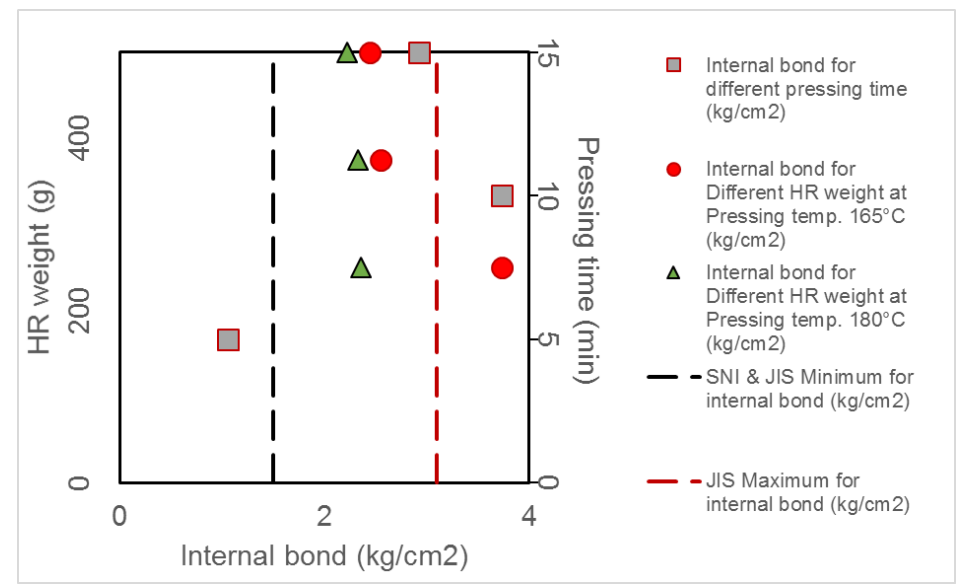

Figure 3. Effect of different HR weight and pressing time on internal bond

standard referred from SNI or JIS standard, it was tested and analyzed to study its potential as an exterior utility.

Particleboard density was measured according to this equation:

$$
\text { Density }\left(\mathrm{g} / \mathrm{cm}^{3}\right)=\mathrm{W} / \mathrm{V}
$$

$\mathrm{W}$ is weight in $\mathrm{g}$, where $\mathrm{V}$ is volume in $\mathrm{cm}^{3}=$ length $(\mathrm{cm}) \mathrm{x}$ wide $(\mathrm{cm}) \mathrm{x}$ thick $(\mathrm{cm})$. According to Indonesian standard (SNI), the value of density should be fall between $0.40 \mathrm{~g} / \mathrm{cm}^{3}-0.90 \mathrm{~g} / \mathrm{cm}^{3}$.

Particleboard moisture content was measured according to this equation

Moisture content $(\%)=\left(\mathrm{W}_{\mathrm{i}}-\mathrm{W}_{\mathrm{d}}\right) / \mathrm{Bk} \times 100 \%$

$\mathrm{W}_{\mathrm{i}}$ is initial weight in $\mathrm{g}$, while $\mathrm{W}_{\mathrm{d}}$ is oven dry weight in g. According to SNI, the value of moisture content of particleboard should not exceed 14\%.

Particleboard thickness swelling was measured according to this equation:

Thickness swelling $(\%)=\left(T_{2}-T_{1}\right) \times 100 \% / T_{1}$

$\mathrm{T}_{1}$ is particleboard initial thickness before water immersion in $\mathrm{mm}$, while $T_{2}$ is thickness after water immersion in mm. According to SNI, the value of thickness swelling after water immersion should not exceed 25\%, based on standard for particleboard with thickness $\leq 12,7$ $\mathrm{mm}$.
In this study, the particleboard surface was also being studied using Scanning Electron Microscope (SEM) to analyze surface morphology and to compare surface fibers-HDPE arrangement between HR with and without the addition of WA or HDPE. The data were also compared with commercial GRC (Glass-fiber Reinforced Cement) Particleboard. The analysis of the heavy metals on the immersion water from procedure 2.2 .5 were also conducted to study its leachate potential considering its possible utility as house exterior. The leaching procedures were conducted based from SNI 19.6365:2000, while the heavy metals analysis were conducted based from SNI 6989.71:2009 (Cr), SNI 6989.16:2009 (Cd), SNI 6989.6:2009 (Cu), and SNI 6989.8:2009 $(\mathrm{Pb})$. The results were then compared to Indonesian standards from KEP-03/BAPEDAL/09/1995.

\section{RESULT AND DISCUSSION}

\subsection{Effect of sample weight and temperature}

Figure $2 \mathrm{a}$ showed that the addition of sample weight may increase the density of particleboard and make it more rigid and compact. The increment of density was occurred due to more fibers and plastics at the same particleboard thickness $(1 \mathrm{~cm})$. Additional of $\mathrm{HR}$ weight from $250 \mathrm{~g}$ to $500 \mathrm{~g}$ may increase density from 0.83 to 1.03 $\mathrm{g} / \mathrm{cm}^{3}$ at $165^{\circ} \mathrm{C}$ pressing temperature, and from 0.9 to 1.01 $\mathrm{g} / \mathrm{cm}^{3}$ at 180 pressing temperature. 

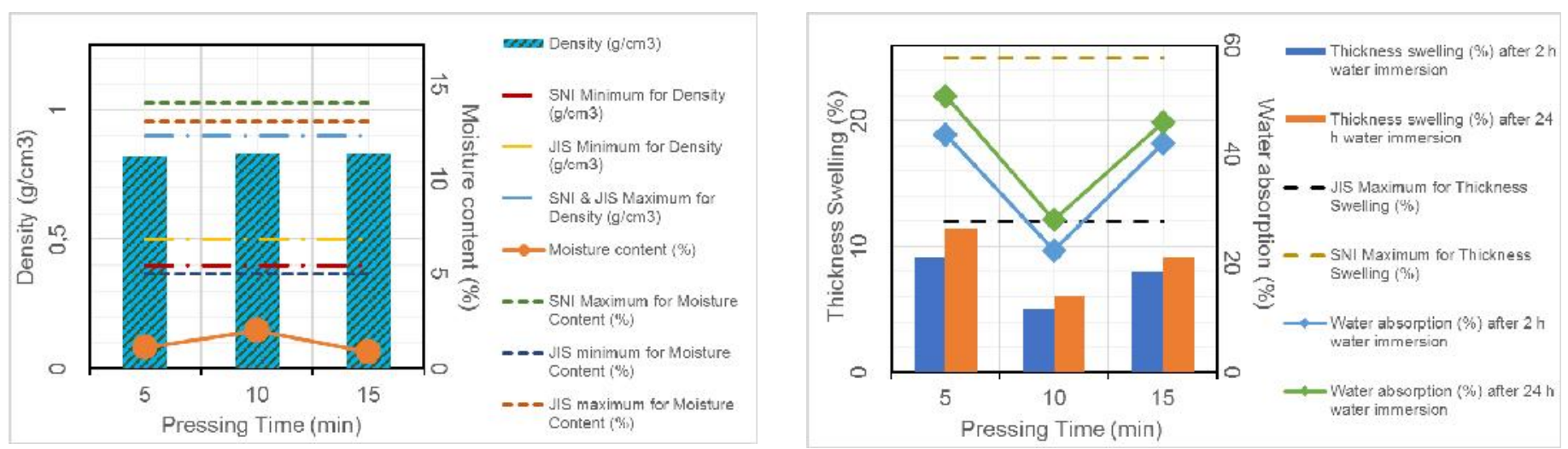

Figure 4. Effect of pressing time on density, moisture content, thickness swelling and water absorption at a constant HR weight $(250 \mathrm{~g})$ and pressure temperature $\left(165^{\circ} \mathrm{C}\right)$

Beside density increment, more HR weight would also indicate a decrement to particleboard moisture content, from $2.01 \%$ at $250 \mathrm{~g}$ HR weight into $0.41 \%$ at $500 \mathrm{~g} \mathrm{HR}$ at $165^{\circ} \mathrm{C}$ pressing temperature. The decrement also occurred at $180^{\circ} \mathrm{C}$ pressing temperature. The moisture content decrement was occurred due to less particleboard space that could be filled with water.

Figure 2a showed that HR weight more than $250 \mathrm{~g}$ did not show adequate data for both SNI and JIS standard except for a sample for $375 \mathrm{~g}$ and $180^{\circ} \mathrm{C}$ pressing temperature. It was also showed that all moisture contents were adequate for SNI standard but inadequate for JIS standard.

Another effect caused by the weight HR addition was the decrement of water absorption of particleboard, both after 2 and 24 hours of water immersion (Figure $2 \mathrm{~b}$ ). Particleboard from $250 \mathrm{~g}$ HR with $165^{\circ} \mathrm{C}$ pressing temperature has water absorption of $22.42 \%$, while particleboard from $500 \mathrm{~g}$ HR with the same pressing temperature has a lower water absorption (6,03\%). The longer water immersion time, water absorption increased, while with more HR weight will give a lower water absorption. The same effect also tended to occur at the particleboard with $180^{\circ} \mathrm{C}$ pressing temperature. While the effect on thickness swelling is not clearly showed on all treatment, it can clearly showed that at $180^{\circ} \mathrm{C}$ and water immersion for 2 hours, the addition of HR weight caused a decrement of thickness swelling. Meanwhile, all data showed that more immersion time will give higher thickness swelling and water absorption value, which are coherent with the previous study (Khanjanzadeh, Bahmani, Rafighi, \& Tabarsa, 2012).

From Figures 2a and 2b, it was also indicated that the increment of pressing temperature from $165^{\circ} \mathrm{C}$ into $180^{\circ} \mathrm{C}$, tend to increase density (for HR weight $250 \mathrm{~g}$ ) and water absorption value but tend to decrease thickness swelling (with the exclusion of HR weight $250 \mathrm{~g}$ ) and internal bond (Figure 3), which were coherent with results from $\mathrm{Li}$ et al., (2009). It was showed from Figure $2 \mathrm{~b}$ that particleboards with HR weight of 250 and $500 \mathrm{~g}$ both with 165 and $180^{\circ} \mathrm{C}$ pressing temperature, and particleboard with $\mathrm{HR}$ weight $375 \mathrm{~g}$ and $180^{\circ} \mathrm{C}$ pressing temperature have surpassed the SNI and JIS thickness swelling value.

Meanwhile, at Figure 2c it was clearly seen that all samples have low $\mathrm{MoE}$ and $\mathrm{MoR}$, and far from adequate for SNI nor JIS standard. Chemical addition of MA to particleboard mixture was made to study its effect on MoR and $\mathrm{MoE}$ and discussed later on subsequent section.

From Figure 3 it was seen that the highest internal bond value was reached at $250 \mathrm{~g} \mathrm{HR}$ weight and $165^{\circ} \mathrm{C}$ pressing temperature, while the lowest one was reached at $500 \mathrm{~g} \mathrm{HR}$ weight and $180^{\circ} \mathrm{C}$ pressing temperature. It was showed that HR weight increment may not guarantee an increment in particleboard internal bond value. The increasing amount of HDPE also supposed to be may increase particleboard internal bond, however the impurities within HR might have interfered with the internal bond value. 


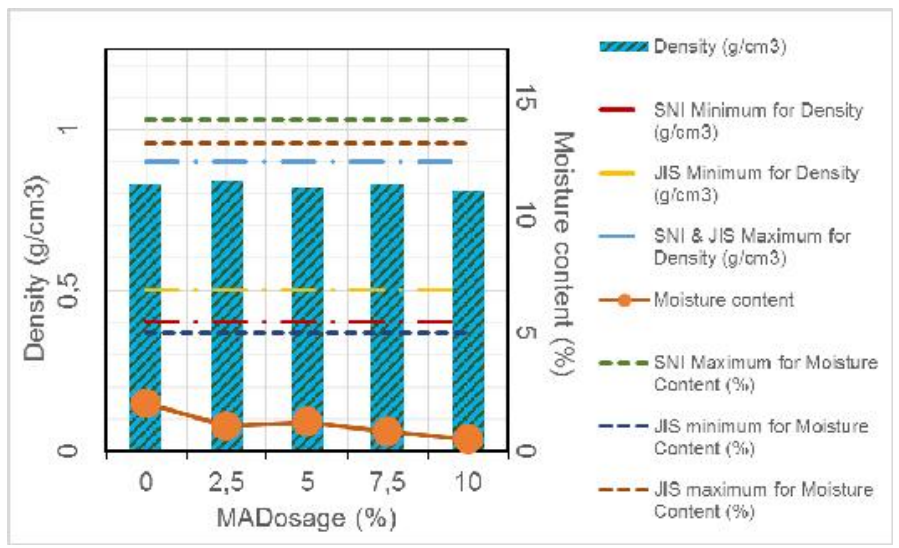

(a)

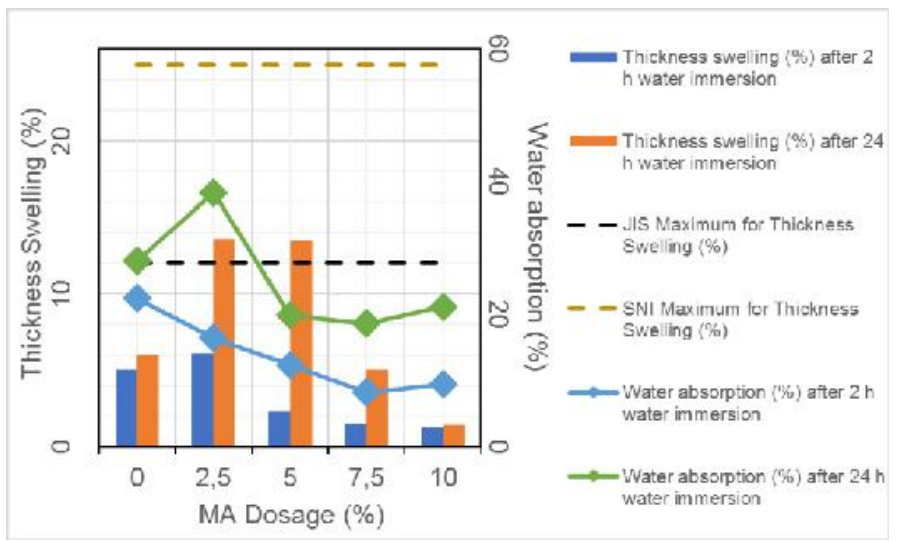

(b)

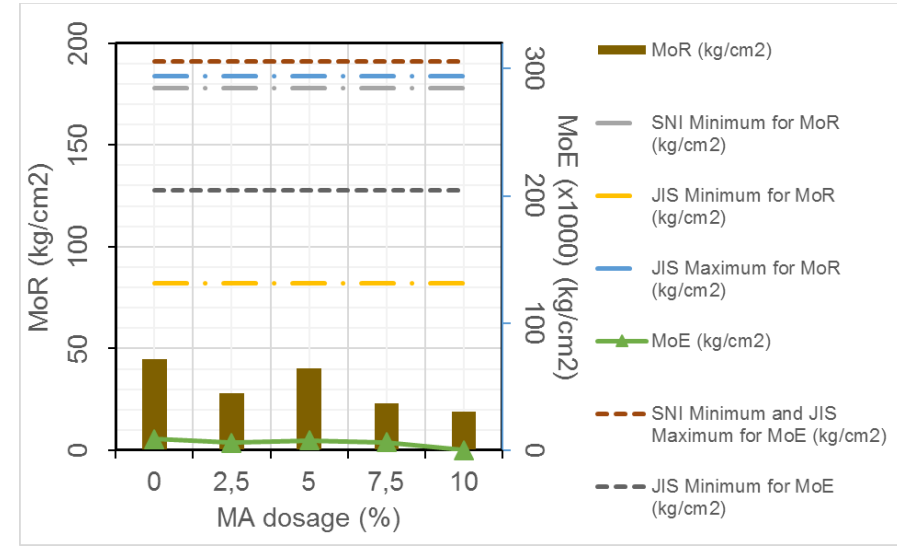

(c)

Figure 5. Effect of MA dosage on density, moisture content, thickness swelling, water absorption, MoR and MoE at a constant HR weight $(250 \mathrm{~g})$ and pressure temperature $\left(165^{\circ} \mathrm{C}\right)$ for 10 minutes

Most of the samples are adequate for SNI for internal bond, with only 5 minutes pressing time sample showed an inadequate data for SNI standard. Meanwhile, JIS standard was not achieved for samples with $250 \mathrm{~g} \mathrm{HR}$ weight, $165^{\circ} \mathrm{C}$ pressing temperature, and less than 15 minutes pressing time.

\subsection{Effects of pressing time}

The data on Figure 4a showed that there were no significant density differences $\left(0.82-0.83 \mathrm{~g} / \mathrm{cm}^{3}\right)$ at the pressing time variation in this study (5-15 minutes). The best internal bond was reached at pressing time of 10 minutes which was $3.73 \mathrm{~kg} / \mathrm{cm}^{3}$ (Figure 3), which also gave the smallest thickness swelling (5.07 and 6.08\% respectively for 2 and 24 hours) and water absorption (22.42 and $28.01 \%$ respectively for 2 and 24 hours), and were adequate for SNI standards for particleboard. Additional pressing time more than 10 minutes did not give any better results (Figure 4b). All samples showed adequate density and thickness swelling both for SNI or JIS, while moisture content was only adequate for SNI.

\subsection{Effects of $M A$ addition}

Generally, the MA addition will going to have some increment effects on mechanical and physical properties of particleboard such as density (Fathanah, 2011; Li et al., 2009). In this study, density was increase from 0.83 to 0.84 $\mathrm{g} / \mathrm{cm}^{3}$ at the $2.5 \% \mathrm{MA}$ addition to the HR particleboard (Figure 5a). The density increment was probably caused by a more compact of particleboard matrix because the additional MA has dissolved some of the impurities and 


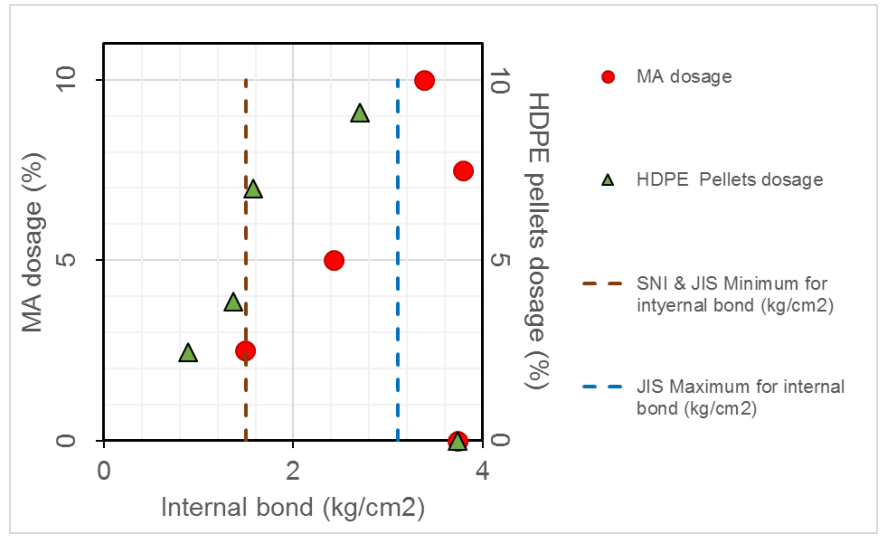

Figure 6. Effect of MA and HDPE dosage on internal bond

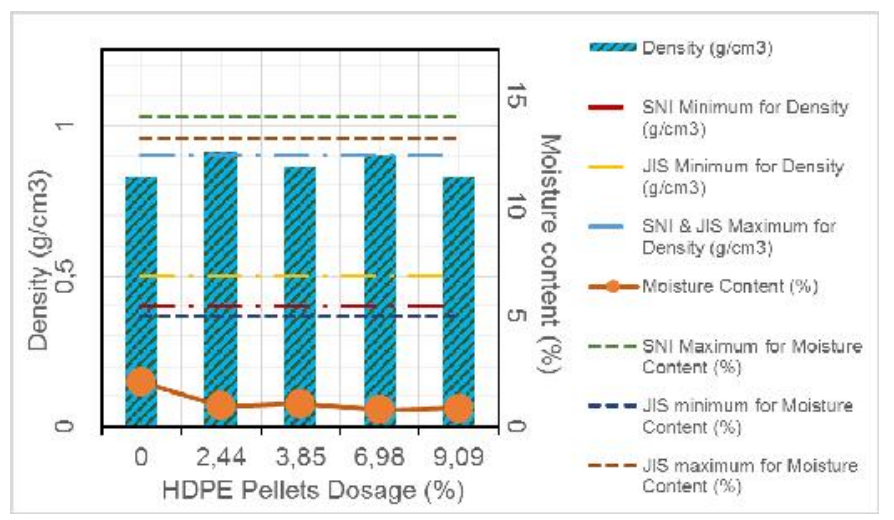

(a)

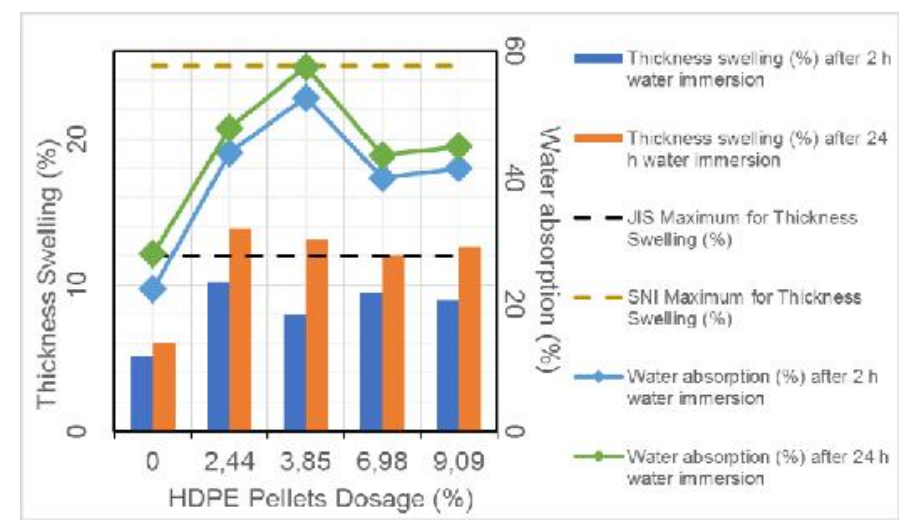

(b)

Figure 7. Effect of HDPE dosage on density, moisture content, thickness swelling and water absorption at a constant HR weight $(250 \mathrm{~g})$ and pressure temperature $\left(165^{\circ} \mathrm{C}\right)$

filled some particleboard pores by fines (Sawpan, Pickering, \& Fernyhough, 2011).

The increment of density also may be occurred due to the crystallinity increment from MA reaction with the end of crystallinity chain which may caused an opening in hydrogen bond and conversion crystallinity to be more amorphous (Sawpan et al., 2011). However, further addition of MA did not show any increment to density of particleboard.

On the other side, similar with some previous results (Fathanah, 2011; Mishra, Naik, \& Patil, 2000; Nourbakhsh \& Ashori, 2010), the MA addition may decrease moisture content and internal bond due to its function as compatibilizer. However, MA dosages more than $2.5 \%$ caused a decrement of water absorption and increment of internal bond in this study (Figures $5 \mathrm{~b}$ and 6).
We will study furthermore the effect of MA addition with SEM analysis and discussed later on this paper.

Nevertheless, the data on Figure 5 and 6 showed that the addition of MA dosage may change the properties of the particleboard, and most of the properties has showed an adequate quality for SNI or JIS standard for given parameters. However, MoR and MoE values were still far from adequate, and moreover the addition of MA was negatively affected to the quality of the particleboard (Figure 5c).

\subsection{Effects of the addition of HDPE pellets}

Theoretically, the addition of HDPE pellets to the particleboard may increase density and internal bond, while also decrease moisture content, water absorption, and thickness swelling, due to its hydrophobic property. 


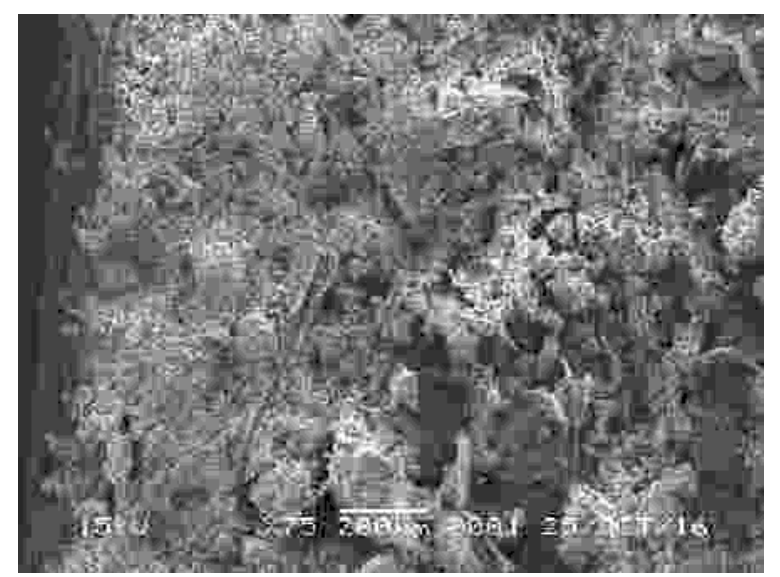

a. GRC Particleboard

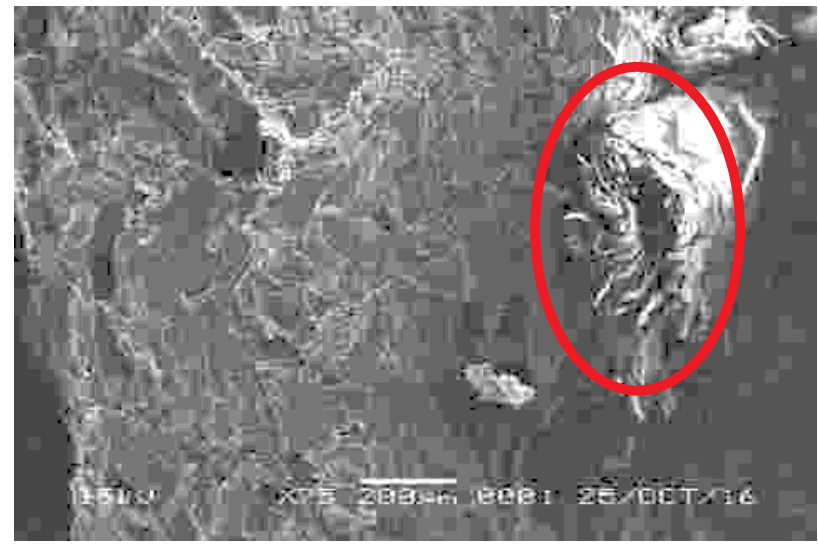

c. HR with MA addition

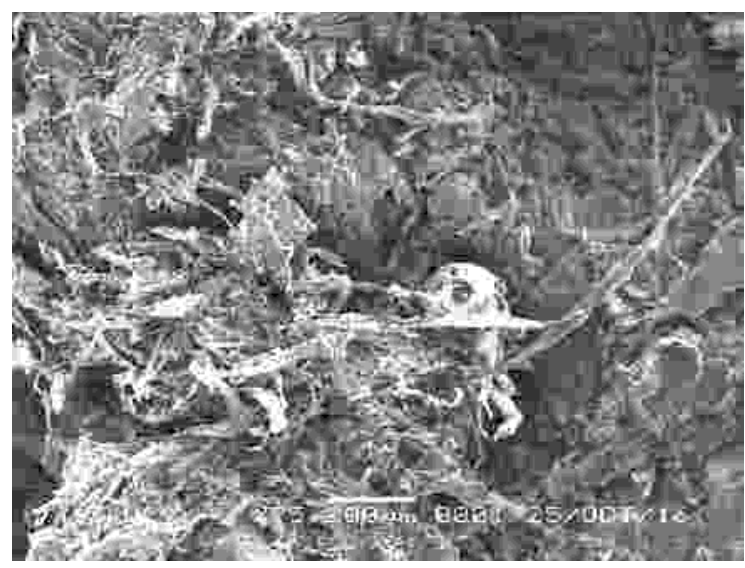

b. HR without MA or HDPE addition

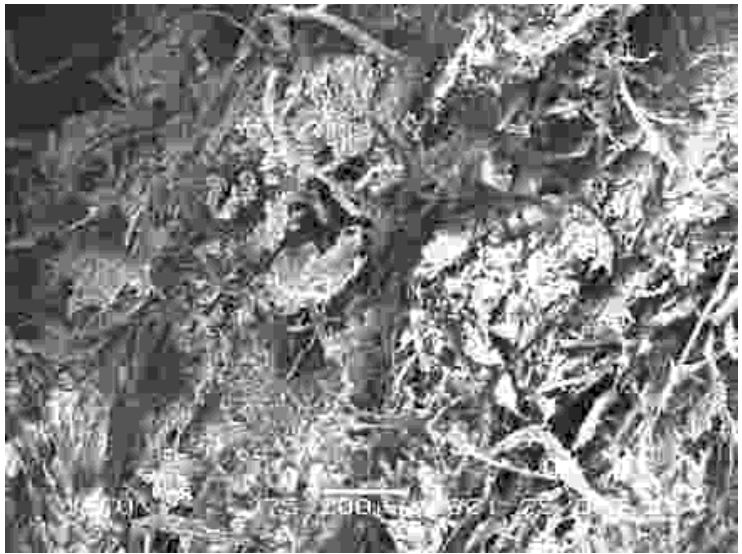

d. HR with HDPE addition

Figure 8. SEM analysis on MA or HDPE addition

Previous study also showed that the addition of HDPE content may increase internal bond, and decrease water absorption and thickness swelling of particleboard (Li et al., 2009). In this study we found that HDPE addition may indicated an increment of density and decrement of moisture content, however this study also indicated an increment of thickness swelling and water adsorption due to HDPE addition. We will also study furthermore the effect of HDPE addition with SEM analysis and discussed later on this paper.

The data indicated that the addition of HDPE pellets may change the properties of the particleboards. For all given parameters (density, moisture content, and thickness swelling), the addition of HDPE pellets above $3.85 \%$ showed an adequate quality for SNI standard, and only for the addition of HDPE pellets above $6.98 \%$ showed an adequate result for both SNI and JIS standard (Figure 7).

\subsection{SEM Analysis}

From SEM data, it was indicated that GRC particleboard has smaller fiber size and fewer fiber content, compared to HR samples that relatively has larger fiber size and more fiber content. The large size and fibers contents may potentially create porosity and entry points for water infiltration, as water might infiltrate through the uncovered fiber that filled the particleboard. Furthermore, mixing and homogeneity of fiber and adhesive also took an important effect on physical properties of particleboard (Iswanto, Febrianto, Hadi, Ruhendi, \& Hermawan, 2012). A less homogeneity particleboard may create porosity 
Table 2. Heavy metals content on particleboard

\begin{tabular}{cccc}
\hline No & Parameters & Results (mg/L) & $\begin{array}{c}\text { KEP- } \\
\text { 03/BAPEDAL/09/1995 }\end{array}$ \\
\hline 1 & $\mathrm{Ag}$ & $<0.01$ & 5.0 \\
2 & $\mathrm{As}$ & $<0.01$ & 5.0 \\
3 & $\mathrm{Ba}$ & 0.10 & 100 \\
4 & $\mathrm{Hg}$ & $<0.01$ & 0.2 \\
5 & $\mathrm{Zn}$ & 0.53 & 50 \\
6 & $\mathrm{Cu}$ & $<0.01$ & 10 \\
7 & $\mathrm{~Pb}$ & $<0.01$ & 0.5 \\
8 & $\mathrm{Cd}$ & $<0.01$ & 1.0 \\
9 & $\mathrm{Cr}$ & $<0.01$ & 5.0 \\
10 & $\mathrm{Se}$ & $<0.01$ & 1.0 \\
\hline
\end{tabular}

(Gawdzinska, Wojnar, Malinski, \& Chraponski, 2010) thus created possible entry points for water infiltration.

MA addition which has hygroscopic characteristic may react with HDPE which has hydrophobic characteristic, and may cause a decrement of moisture content of particleboard. As seen on Figure 8 (c), MA addition to particleboard created a more clotted surface and caused a more compact particleboard compared to particleboard without it (b). However, there are still more fiber content compared to GRC particleboard which leads to potential entry points for water infiltration. On the other side, the addition of HDPE pellets caused an increment of density and decrement of moisture content, however as indicated on Figure 8 (d), there were a lot of large fiber size and fiber contents on the particleboard. This may increase the thickness swelling and water adsorption due to entry points for water infiltration from the fibers.

\subsection{Heavy Metals Analysis}

Table 2 and 3 showed that the HR particleboard and the water from the particleboard immersion process contained low heavy metals content below the applied regulation. These tests ensured that the heavy metals content from the particleboard and from the leachates that originated from HR particleboard were still acceptable to
Table 3. Heavy metals concentration on soaked water of particleboard

\begin{tabular}{cccccc}
\hline \multirow{2}{*}{ No } & Sample & \multicolumn{4}{c}{ Concentration $(\mathrm{mg} / \mathrm{L})$} \\
\cline { 3 - 6 } & & $\mathrm{Cr}$ & $\mathrm{Cd}$ & $\mathrm{Cu}$ & $\mathrm{Pb}$ \\
\hline 1 & R-165-15 & nd & nd & nd & nd \\
2 & RPE-9.09 & nd & nd & nd & nd \\
3 & GRC-Particleboard & nd & nd & nd & nd \\
\hline KEP-03/BAPEDAL/09/1995 & nd & nd & nd & nd \\
\hline
\end{tabular}

Note: nd $=$ not detected

the Indonesian standard, and thus HR particleboard is safe to be utilized as an interior and exterior.

\section{CONCLUSION}

Although all the samples could not meet MoR and MoE standards for both SNI and JIS, the results showed that most of the samples were relatively accepted to other standards on the SNI. Meanwhile, besides water content, most of the samples were also relatively accepted to JIS standards. Best results were achieved at the HR weight of $250 \mathrm{~g}$ with 165 and $180^{\circ} \mathrm{C}$ pressing temperature, and pressing time more than 10 minutes. The addition of HDPE pellets indicated an increment of density and decrement of moisture content, while the addition of MA indicated some decrements of moisture content and water absorption. Mixing and homogeneity of fiber and adhesive also took an important effect on physical properties of particleboard. A less homogeneity particleboard may create porosity and entry points potency for water infiltration.

There was no significant heavy metal concentration found on the HR particleboard nor the soaked water of HR particleboard. Thus according to this study, application of HR particleboard both for interior or exterior utilization are relatively safe to the environment. 


\section{ACKNOWLEDGEMENT}

The authors are very grateful for the support provided by Center for Pulp and Paper (CPP), Ministry of Industry of Indonesia, and also for the support from fellow colleagues and researchers from CPP: Aep Surachman, Kristaufan Joko Pramono, Sri purwati, and Henggar Hardiani.

\section{REFERENCES}

Ashori, A. R., \& Nourbakhsh, A. (2014). Fiber reinforced plastic composites using recycled materials. International Journal of Lignocellulosic Products, 1(1), 28-38.

Atuanya, C. U., Ibhadode, A. O. A., \& Igboanugo, A. C. (2011). Potential of Using Recycled Low-density Polyethylene in Wood Composites Board. African Journal of Environmental Science and Technology, 5(5), 389-396. Retrieved from http://www.academicjournals.org/AJEST

CAMEO Chemicals. (1999). Maleic anhydride. Retrieved February 21, 2019, from https://cameochemicals.noaa.gov/chemical/3806

Faruk, O., \& Matuana, L. M. (2008). Nanoclay Reinforced HDPE as a Matrix for Wood-plastic Composites. Composites Science and Technology Journal, 68 (9), 2073-2077. https://doi.org/10.1016/ j.compscitech.2008.03.004

Fathanah, U. (2011). Kualitas Papan Komposit dari Sekam Padi dan Plastik HDPE Daur Ulang Menggunakan Maleic Anhydride ( MAH ) sebagai Compatibilizer. Jurnal Rekayasa Kimia Dan Lingkungan, 8(2), 5359. Retrieved from http:// www.jurnal.unsyiah.ac.id/RKL/article/view/741

Gavrilescu, D. (2008). Energy from Biomass in Pulp and Paper Mills. Environmental Engineering and Management Journal, 75), 537-546. Retrieved from http://www.eemj.icpm.tuiasi.ro/pdfs/vol7/ no5/9_Gavrilescu_D.pdf

Gawdzinska, K., Wojnar, L., Malinski, M., \& Chraponski, J. (2010). Structure Homogeneity as a Parameter for Evaluation of Composite Casting Quality. Archives of Foundry Engineering, 10(3), 187-192. Retrieved from https://www.researchgate.net/ publication/267562341

Harshavardhan, A., Muruganandam, L., \& Ranjitha, J. (2016). A Review Report on Physical and Mechanical Properties of Particle Boards from Organic Waste. International Journal of ChemTech Research, 9(1), 64-72. Retrieved from http://www.sphinxsai.com/2016/ch_vol9_no1/1/( 64-72)V9N1CT.pdf

Haynes, R. D., Malloch, J., Cuddy, K., \& Nicodimos, E. (2009). Ask the Recycle Mill Gals. Progress in Paper Recycling, 18(3), 13-20.

Iswanto, A. H., Febrianto, F., Hadi, Y. S., Ruhendi, S., \& Hermawan, D. (2012). Sifat Fisis dan Mekanis Papan Partikel dari Kulit Buah Jarak (Jatropha curcas) Diperkuat Partikel Kayu (Physical and Mechanical Properties of Particleboard Made from Jatropha (Jatropha curcas) Fruit Hulls Reinforced with Wood Particle). Jurnal Ilmu Dan Teknologi Kayu Tropis, 10(2), 103-111. Retrieved from https://www.researchgate.net/publication/273130 440_Physical_and_mechanical_properties_of_part icleboard_made_from_jatropa_Jatropha_curcas_fr uit_hulls_reinforced_with_wood_particles

Khanjanzadeh, H., Bahmani, A. A., Rafighi, A., \& Tabarsa, T. (2012). Utilization of Bio-waste Cotton (Gossypium hirsutum L .) Stalks and Underutilized Paulownia (Paulownia fortunie) in Wood-based Composite Particleboard. African Journal of Biotechnology, 11(31), 8045-8050. https://doi.org/10.5897/AJB12.288

Li, B., Zheng, Y., Pan, Z., \& Hartsough, B. (2009). Improved Properties of Medium-density Particleboard Manufactured from Saline Creeping Wild Rye and HDPE Plastic. Industrial Crops and Products, 30(1), 65-71. https://doi.org/10.1016/ j.indcrop.2009.01.006

Maloney, T. M. (1977). Modern Particleboard \& Dryprocess Fiberboard Manufacturing. San Francisco: 
Miller Freeman.

Matmatch. (2019). General Polyethylene, high density ( PE-HD ). Retrieved August 29, 2018, from https://matmatch.com/materials/mbas008general-polyethylene-high-density-pe-hd-

Mawardi, I. (2009). Mutu Papan Partikel dari Kayu Kelapa Sawit ( KKS ) Berbasis Perekat Polystyrene. Jurnal Teknik Mesin, 11(2), 91-96. https://doi.org/ https://doi.org/10.9744/jtm.11.2.pp.\%2091-96

Mishra, S., Naik, J. J., \& Patil, Y. P. (2000). The Compatibilising Effect of Maleic Anhydride on Swelling and Mechanical Properties of Plant-fiberreinforced Novolac Composites. Composites Science and Technology, 60(9), 1729-1735. https://doi.org/10.1016/S0266-3538(00)00056-7

Nourbakhsh, A., \& Ashori, A. (2010). Particleboard Made from Waste Paper Treated with Maleic Anhydride. Waste Management \& Research, 28(1), 51-55. https://doi.org/10.1177/0734242X09336463

Sawpan, M. A., Pickering, K. L., \& Fernyhough, A. (2011). Effect of Various Chemical Treatments on the Fibre Structure and Tensile Properties of Industrial Hemp Fibres. Composites Part A: Applied Science and Manufacturing, 42(8), 888-895. https:// doi.org/10.1016/j.compositesa.2011.03.008

Septiari, I. A. P. W., Karyasa, I. W., \& Kartowarsono, N. (2014). Pembuatan Papan Partikel dari Limbah Plastik Polyprophylene (PP) dan Tangkai Bambu. E-Journal Kimia Visvitalis, 2(1), 117-126. Retrieved from https://ejournal.undiksha.ac.id/ index.php/JJPK/article/download/4027/3181

Setiawan, Y., Purwati, S., Surachman, A., Bastari, R. I. W., \& Hardiani, H. (2014). Pelet Reject Industri Kertas sebagai Bahan Bakar Boiler. Jurnal Selulosa, $4(2)$, 57-64. https://doi.org/http://dx.doi.org/ 10.25269/jsel.v4i02.87

Setiawan, Y., \& Surachman, A. (2015). Reject Waste Pellets of Paper Mills as Fuels and Their Contribution to Greenhouse Gas (GHG). International Journal of Technology, 6(5), 847-855. https://doi.org/ 10.14716/ijtech.v6i5.1790

Wardani, L., Massijaya, M. Y., \& Machdie, M. F. (2013). Pemanfaatan Pelepah Sawit dan Plastik Daur Ulang (RPP) sebagai Papan Komposit Plastik. Jurnal Hutan Tropis, 1(1), 46-53. Retrieved from https://ppjp.ulm.ac.id/journal/index.php/jht/articl e/download/1483/1273 